\title{
Applications of beneficial plant growth promoting rhizobacteria and mycorrhizae in rhizosphere and plant growth: A review
}

\author{
Ashiq Khan ${ }^{1,2,3}$, Zitong Ding ${ }^{1,3}$, Muhammad Ishaq ${ }^{1,3}$, Israr Khan ${ }^{4}$, Anum Ali Ahmed ${ }^{4}$, \\ Abdul Qadir Khan ${ }^{4}$, Xusheng Guo ${ }^{1,3 *}$ \\ (1. Key Laboratory of Grassland and Agro-ecosystems, School of Life Sciences, Lanzhou University, Lanzhou 730000, China; \\ 2. Department of Microbiology, Balochistan University of Information Technology Engineering \& Management Sciences Quetta 87300, \\ Pakistan; \\ 3. Probiotics and Biological Feed Research Center, Lanzhou University, Lanzhou 730000, China; \\ 4. School of Life Sciences, Institute of Microbiology Lanzhou University, Lanzhou 730000, China)
}

\begin{abstract}
Because of climate change and the highly growing world population, it becomes a huge challenge to feed the whole population. To overcome this challenge and increase the crop yield, a large number of fertilizers are applied but these have many side effects. Instead of these, scientists have discovered beneficial rhizobacteria, which are environmentally friendly and may increase crop yield and plant growth. The microbial population of the rhizosphere shows a pivotal role in plant development by inducing its physiology. Plant depends upon the valuable interactions among the roots and microbes for the growth, nutrients availability, growth promotion, disease suppression and other important roles for plants. Recently numerous secrets of microbes in the rhizosphere have been revealed due to huge development in molecular and microscopic technologies. This review illustrated and discussed the current knowledge on the development, maintenance, interactions of rhizobacterial populations and various proposed mechanisms normally used by PGPR in the rhizosphere that encouraging the plant growth and alleviating the stress conditions. In addition, this research reviewed the role of single and combination of PGPR, mycorrhizal fungi in plant development and modulation of the stress as well as factors affecting the microbiome in the rhizosphere.
\end{abstract}

Keywords: rhizosphere, plant growth promoting rhizobacteria, mycorrhizae, nitrogen fixing bacteria, phosphate solubilizing bacteria

DOI: $10.25165 /$ j.ijabe.20201305.5762

Citation: Khan A, Ding Z T, Ishaq M, Khan I, Ahmed A A, Khan A Q, et al. Applications of beneficial plant growth promoting rhizobacteria and mycorrhizae in rhizosphere and plant growth: A review. Int J Agric \& Biol Eng, 2020; 13(5): 199-208.

\section{Introduction}

Rhizosphere is an area around the plant roots and surrounding soil. The word 'rhizosphere' for the first time was defined as the area of highest bacterial activities ${ }^{[1]}$. Microbial population present in this atmosphere is comparatively diverse from that of its bulk soil because of root exudates which function as a source of nourishment for microbes ${ }^{[2]}$. Research has shown that several plants associated microbes can have concentrating effects on plant growth, nutrients, seed germination and disease management ${ }^{[3,4]}$. In plant-microbe association, plants could be regarded as a superorganism that relies on microbes for their particular functions

Received date: 2020-03-05 Accepted date: 2020-05-07

Biographies: Ashiq Khan, PhD candidate, Professor, research interest: PGPR, probiotics, gut microbiota, NAFLD and biofeed research. Email: ashiq2017@lzu.edu.cn; Zitong Ding, PhD, research interest: probiotics and biofeed research. Email: dingwr@lzu.edu.cn; Muhammad Ishaq, PhD candidate, Professor, research interest: probiotics and biofeed research, Email: ishaq2017@lzu.edu.cn; Israr Khan, PhD, research interest: probiotics, gut microbiota and IBD, Email: israrf.mkhan122@gmail.com; Anum Ali Ahmed, PhD candidate, research interest: biofeed research, Email: anum2017@ lzu.edu.cn; Abdul Qadir Khan, PhD, research interest: PGPR, microbial eology, Email: aqadir953@gmail.com.

*Corresponding author: Xusheng Guo, PhD, Professor, research interest: agricultural ecology, probiotics, gut microbiota, NAFLD and biofeed research. State Key Laboratory of Grassland Agro-ecosystems, School of Life Sciences, Lanzhou University, Lanzhou 730000, China. Tel: +86-931-8915650, Email: guoxsh07@lzu.edu.cn. as well as traits. In response, plants deposited their photosynthetic carbon in their surroundings, rhizosphere as well as mycorrhizosphere ${ }^{[5,6]}$. Thus, the plant-microbe association is beneficial in nourishing the microbial population and prompting its composition and activities. So far, the interactions among the plants and microbes have been studied comprehensively in many leaf pathogens, rhizobia similarly in mycorrhizae. Nevertheless, for the majority of plant-associated microbes, limited data exists on its effects on plant growth and development, disease management. Therefore, plant-microbe interactions are extremely important to identify the beneficial microbes that could improve plant growth. This review summarized the key aspects of PGPR and mycorrhizae and highlighted its role in plant growth and development. In addition, the effectiveness of inoculum with valuable rhizobacteria and mycorrhizae alone as well as in combination with plant growth and development has also been discussed.

\section{Rhizosphere as the source of beneficial microorganisms}

The rhizosphere, defined as the area often spreading a few millimeters to the surface of the root ${ }^{[7]}$. This area of the soil is enriched in bacteria other than nearby bulk soil ${ }^{[1]}$. Its population mainly comprises bacteria, actinomycetes, algae, protozoa and fungi. However, rhizobacterial communities prodigiously occur in the rhizosphere ${ }^{[8,9]}$. The development of plant growth via the use of these microorganisms is well known ${ }^{[10]}$. Nevertheless, to maintain the positive effects of the microbes in the rhizosphere, 
bacteria need to compete well with other rhizobacterial for minerals produced through roots exudates. Interactions among the plant as well as rhizosphere are important to acquire water and nutriment from the soil and these interactions are favorable to both plant roots and rhizosphere ${ }^{[11]}$.

Studies using molecular techniques have assessed that above 4000 bacterial sp. exist in one gram of the soil ${ }^{[12]}$. Actinobacteria is recognized as one of the significant microbial populations in the rhizosphere ${ }^{[13]}$, which can protect its roots from phytopathogens ${ }^{[14]}$. These microbes in the rhizosphere can influence the plant growth $^{[15]}$, either positively in the symbiotic way or negatively in pathogens as well as predator's way ${ }^{[16-18]}$. However, the rhizosphere affects plant development and sustains the stress as well as its significant role needs more attention ${ }^{[19]}$.

Non-culture able methods have revealed that the microbial population in soil and rhizosphere is extremely underrated. The next-generation sequencing has established that only a smaller amount of bacterial population has been cultured through the current approaches and a major ratio of bacterial phyla identified through these tools has no cultured representative so far $^{[7,20]}$. Torsvik et al. ${ }^{[21]}$ assessed the quantity of bacterial population in the forest soil. Succeeding the same approach with significant computational developments, this research estimated that one gram of the soil could contain above one million distinctive bacterial species $^{[22]}$. Developments in sequencing mechanisms have helped to explore rhizosphere studies ${ }^{[23,24]}$. Some studies have concentrated its focus on the number and diversity of the bacterial taxa in the rhizosphere. Depending on the methods used, microorganisms isolated in the rhizosphere vary from $<100$ to over 55000 OTUs. In a meta-analysis, 19 clones of libraries were obtained from the rhizosphere of 14 plant species and have shown about 1200 different bacterial taxa from the 35 diverse taxonomic orders, with the Proteobacteria record as a dominant phylum ${ }^{[25]}$. In many rhizosphere studies, samples isolated from the Antarctic, Firmicutes were noted as an abundant phylum, while in the other rhizosphere studies, Proteobacteria were frequently more abundant. Using 16S rRNA gene array, authors identified 2595 OTUs in the oat rhizosphere with 1917 OTUs constantly present in total replicates, dominated by the Actinobacteria, Proteobacteria as well as Firmicutes ${ }^{[26]}$. Based on the 454 pyrosequencing, Uroz et al. revealed that ectomycorhizosphere of the Xerocomus pruinatus, as well as Scleroderma citrinum, presented a higher value of alpha $(\alpha)$, beta $(\beta)$ and gamma $(\gamma)$ proteobacteria other than bulk soil ${ }^{[27]}$. To study the potentially beneficial properties of the culture able and non-culture able microbial diversity of rhizosphere, it is necessary to develop the advanced screening and identifying technology and sequencing techniques. In addition factors, for example, the soil, texture, type, soil moisture, soil temperature, soil $\mathrm{pH}$, humidity, and several other features are recognized, that affects the rhizosphere, and recently it was also investigated that through various means microbes alter the local $\mathrm{pH}$ as well as physical properties of the rhizosphere ${ }^{[28]}$. Therefore, shifts in these parameters have a marked effect on the microbial population of the rhizosphere. Further, studies are required to understand these effects on the rhizosphere, and management of these variations could provide better performance approaches for the rhizosphere microbes.

\section{Effects of rhizobacteria on the plant health}

An important microscopic population which exerts encouraging effects on the plant growth is termed as PGP rhizobacteria (Figure 1) ${ }^{[11,29]}$. PGP rhizobacteria are diverse soil microbes, grown in the association to host plant, such association enhances the growth of the host plant, rhizobia have shown to stimulate the plant growth by monitoring the pathogenic organism and stress circumstances ${ }^{[10,28]}$. These microorganisms usually live more or less closely to plant roots exudates, which are a source of nutrition for its growth ${ }^{[30,31]}$.

A number of bacterial genera for example Bacillus, Azospirillum, Variovorax, Pseudomonas, Azotobacter, Klebsiella, Enterobacter, and Burkholderia, have distinctive effects on plant growth, characterized as PGP rhizobacteria ${ }^{[32,33]}$. Rhizobacteria can increase plant growth via several mechanisms e.g. nutrient recycling, $\mathrm{N}_{2}$ fixation, production of the phytohormone, nutrients solubilization such as, $\mathrm{K}, \mathrm{Fe}$ and $\mathrm{P}$, improve the plant resistance against several pests as well as diseases ${ }^{[11,34]}$. Similarly, they produce siderophores, organic acids and protect the plants through several enzymes ${ }^{[18,25,34,35]}$. Moreover, it plays a significant role in nutrient uptake, root health as well as sustains environmental stress ${ }^{[36]}$. Recent research showed that PGPRs can give various benefits to the plants, such as improving the nutrient acquirement, and also inducing resistance to the plant against biotic as well as abiotic stresses $^{[37]}$.

Studies have identified the specificity of PGPR that varies from species to strain level which confers its support to host plant and evidence available about PGPR effects on the plant traits ${ }^{[38]}$. Researchers are devoting their research struggles in developing the combinations of diverse beneficial microbes that can provide maximum effects to plants and the environment ${ }^{[39]}$. In recent studies, the use of rhizosphere bacteria or PGPR products (pyoverdine, siderophore) has affected the plant response towards nutrients ${ }^{[40,41]}$. It means that this is helpful to plant nourishment. They can also increase the release of different nutrients, scavenging particles for plant growth ${ }^{[42]}$. Similarly, along with the bacterial populations, fungal species also show a major role in the rhizosphere and its microflora influences the plant development. Mycorrhizas have shown to increases the surface area, hence support the plants to absorb more water, nutrients more powerfully from the soil. Ecto-mycorrhizae and endo-mycorrhizal relationships have been studied in several plant sp. This association is not only a rising nutrient and water accessibility but also protects the plants from many abiotic factors $^{[43]}$. This indicates that such beneficial interactions have encouraging effects on plant growth and development. However, it is necessary to maintain these associations for better growth of the plants.

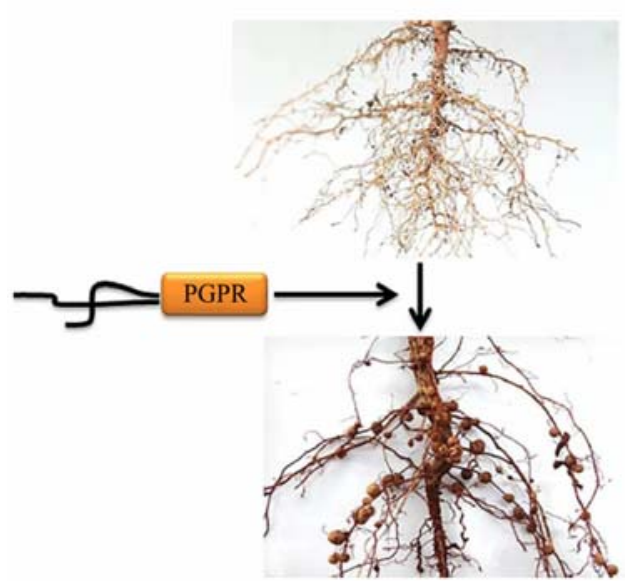

Figure 1 Location of the beneficial rhizobacteria (PGPR) in the plant roots ${ }^{[11]}$ 


\subsection{Significant aspects of beneficial plant promoting Rhizobacteria}

Rhizobacteria living in soil surrounding (rhizosphere) can cause significant variations in the plant development via synthesis of the growth regulators, similarly enabling the nutrients uptake from soil ${ }^{[44,45]}$. Several studies have shown the encouraging properties of the rhizobacteria, which can rise the plant tolerance to the soil, soil salinity, soil heavy metal toxicity, therefore benefit the plants to live in harsh environments ${ }^{[46,47]}$. Many free-living bacteria and some bacterial sp. of the particular genus do not have similar metabolic abilities for improving the plant growth ${ }^{[48]}$. However, PGPRs have shown to inhibit or reduce the damaging effects of pathogens via one or numerous mechanism ${ }^{[49]}$. The suitable mechanism comprises pathogen inhibition by producing defensive substances and increasing the resistance of host plants to pathogenic microbes ${ }^{[50]}$. Further, they ease the plant development via fixing atmospheric $\mathrm{N}_{2}$ and support in the secretion of siderophores which might solubilize the sequestered iron and phytohormones production, similarly solubilize the mineral deposits, for example, phosphorus and increase its availability to plants $^{[49,51]}$. Irrespective of the mechanisms, these beneficial microbes can rise the plant growth by its enzymes as ACC-deaminase and chitinase, similarly, production of exopolysaccharides and rhizobitoxine, that supports plant growth in stress atmospheres ${ }^{[32,36,52,53]}$. Several rhizobacteria might have specific traits as well as affects plant growth through different mechanisms. The effectiveness of beneficial bacterial strains also depends on the host plant as well as soil characteristics and soil atmosphere $^{[54]}$. Overall, PGP rhizobacteria could support plant growth by different approaches. Future studies are required to understand the thorough properties of these beneficial microorganisms.

\section{Does mycorrhizae affect plant development?}

Mycorrhizae are the symbiotic association among the roots of a vascular plant and fungal strains. Arbuscular mycorrhizae and ectomycorrhizae are the most common associations. Arbuscular mycorrhiza is the most copious fungus, usually exists in agricultural soil. It also forms an association with the terrestrial and aquatic plants ${ }^{[55,56]}$. Studies described that about $80 \%$ of the terrestrial plants, containing mostly agricultural and horticultural plants are capable to form this mutualistic relationship ${ }^{[57]}$. The fungus penetrates in roots cortical cells, procedure specific haustoria like structure named as arbuscular, that functions as a mediator for the exchange of the metabolites between fungus and host cytoplasm ${ }^{[58]}$. Mycorrhizae could increase the accessibility as well as transport of diffusing ions, for example, $\mathrm{P}$ to host plants ${ }^{[59,60]}$. Similarly, it shows a vital role in improving soil physical properties. Mycorrhizae mycelium nearby to soil microorganisms produces stable aggregate, therefore improve soil aggregation $^{[61]}$. This progress in soil aggregation because of the production of an unsolvable mass (glycoprotein) by mycorrhizae ${ }^{[62]}$, which shows its significant role in the soil firmness ${ }^{[63]}$. Arbuscular mycorrhiza hyphae flourishing in the soil ${ }^{[64]}$, supports the plant to obtain water, nutrients, from the soil, in addition, it also develops soil texture ${ }^{[65]}$. It illustrates an important role in the ecosystem through nutrient cycling ${ }^{[66,67]}$. Studies have revealed that about $80 \%$ of the $\mathrm{P}$ taken up through plants is supplied by mycorrhizal fungi ${ }^{[68]}$. Arbuscular mycorrhizae could also provide both macros as well as micronutrients for example; N, K, Mg, Zn and $\mathrm{Cu}$ mostly in the soil where it occurs in the less soluble form $^{[68,69]}$. In brief, such association could maintain plant development not only to give nutrients but also maintains plants to tolerate the stress conditions. Studies are anticipated with a better understanding of the mechanisms that can validate this development and its effects on plant growth.

\section{Rhizosphere regulation by microbial interactions or beneficial microbes}

It is the most complex zone for symbiotic, chemical and physical associations. Root exudates many molecules in the rhizosphere ${ }^{[70]}$. In rhizosphere the plant root interactions can include root-microbe, root-insect as well as root-root interactions, ensuing in more production of root exudates, eventually favors more bacterial communities in the rhizosphere. The application of molecular approaches showed that variations in rhizobacterial composition results in vital changes in the plant-microbe interactions $^{[71]}$. In rhizospheric interactions, PGPR might colonize the rhizosphere, root surface, or can even colonize superficially in intercellular spaces ${ }^{[72]}$.

Studies indicated that PGPRs formed a number of molecules through complex mechanisms in the rhizosphere, which vary from the simple amino acids to larger polysaccharides, proteins, different metabolites in the rhizosphere, which severe indirectly as a chemoattractant to other PGPRs ${ }^{[73,74]}$ and also increase the release of different nutrients scavenging particles and have multiple variable effects on the plant physiology ${ }^{[37,42]}$.

Root exudate is a significant source for the growth of microbes in the rhizosphere. These mainly include the ions, water, mucilage, enzymes and diverse primary and secondary metabolites $^{[61]}$. In these metabolic compounds, organic acid shows a major role in the metabolism and biogeochemical reactions in the soil. More, these are specific to plant sp. in quantity and composition and more common in those plants that grow in less nutrient soil and consume root exudates other than the symbiotic relationship to microbial populations in the rhizosphere ${ }^{[73]}$. Nevertheless, the interactions involved in the rhizosphere as a result of exudates are so far not clear ${ }^{[75]}$.

A number of studies have identified the specificity of PGPR from species to strain level which showed its benefits to the host plant and evidence also available about PGPR effect on the plant traits $^{[38,76]}$. Genomic basis studies of these associations can allow the manipulation of rhizospheres, which could encourage as well as induce the plant growth ${ }^{[37,73]}$.

As plant roots, exudates are enormously species-specific, which can explain the specificity of microbial populations to host plants. The study of the complete genome of $P$. putida has shown its significance as stress adopters ${ }^{[77]}$. Clearly, the microbes in the rhizosphere could influence the plants directly via the release of different metabolites, as well as other minute signaling molecules $^{[37]}$.

Several bacterial species are normally related to a small number of or even a single plant sp. like, Rhizobium-legumes association. Likewise, Sinorhizobium meliloti efficiently colonize the genera of plant Medicago, Melilotus as well as Trigonella, where $R$. leguminosarum produces the nodules in the Pisum vicea, similarly in Lathyrus plant ${ }^{[78]}$. Still, it is promising to identify novel taxonomic collections in rhizosphere for example non-thermophilic population of archaeal division crenarchaeota $^{[79]}$. Rhizosphere colonization and its formation in plant roots are essential for effective functions of the rhizosphere population ${ }^{[80]}$. Phases in microbial colonization involve recognition of the specific 
plant host, adherence, invasions to the roots, colonization, development and use of many other methods to start the interactions. Generally, roots initiate the cross talk to the soil microorganisms through the production of signals which are recognized by other microbes, in response produced signals which initiate colonization ${ }^{[78]}$. Motile organisms are mostly preferred as they participate and respond in the cross talk ${ }^{[80]}$. For instance, teeming of the Serratia liquefaciens seemed to be precisely encouraged by the exudates of the Pisum sativum ${ }^{[81]}$. Similarly, phenotypes of the P. fluorescens F113 with higher motility rates were chosen in the rhizosphere colonization of the alfalfa ${ }^{[82]}$.

In addition, not only bacterial species still, fungal species are shown to attach to the root surface. Fungal adhesion to root is a significant step for the formation of symbiotic associations ${ }^{[83]}$. Certain plant-microbe interactions have been shown to establish complex mechanisms for example signal exchange which tolerates specific microbial population in the rhizosphere, e.g. sinorhizobium $^{[84]}$. Simply not only plant microbes' interactions are significant in the rhizosphere, but microbes can also affect one another ${ }^{[10]}$. Nevertheless, to be further effective in the rhizosphere, the PGPR needs to sustain a critical rhizosphere population for the long term ${ }^{[14]}$. Therefore, detailed studies are needed to explore these interactions with a detailed mechanism and study their effects on plant growth.

\section{Do the rhizobacteria and mycorrhizae affect nitrogen fixation and plant growth?}

Nitrogen $\left(\mathrm{N}_{2}\right)$ is the most important element for the plant growth and necessary for the synthesis of the nucleic acid, protein, chlorophyll and enzymes. Although $78 \%$ of the atmosphere comprises of $\mathrm{N}_{2}$, nevertheless its direct assimilation to plants is unavailable ${ }^{[85]}$. It is becoming one of the limiting factors in the agricultural ecosystems because of huge losses of available $\mathrm{N}_{2}$ via heavy rainfall as well as mineral leaching. Presently, many industrial nitrogen fertilizers are used for improving agricultural yield. However, environmental, economic as well as renewable energy fears dictate the usage of biological substitutes ${ }^{[14]}$.

Plant growth promoting rhizobacteria could provide a biologically alternative way to fix atmospheric nitrogen for plant growth $^{[86]}$. Investigations have shown that inoculum of biological nitrogen fixing rhizobacteria on the crops, could stimulate plant growth, disease management as well as sustains the $\mathrm{N}_{2}$ level in the agricultural soil ${ }^{[87]}$. A number of PGPR like, Azoarcus species, Klebsiella pneumoniae, Beijerinckia, Pantoea agglomerans as well as Rhizobium species are described to fix the atmospheric nitrogen in the soil ${ }^{[88]}$ as well as make it accessible to plants ${ }^{[14]}$.

PGPR could fix the atmospheric nitrogen both in symbiotically and non-symbiotically. Symbiotic nitrogen fixation (SNF) to leguminous plants through the inoculation of PGPRs is well identified $^{[89,90]}$. Many rhizobia, for example, Azotobacter, Beijerinckia and Bacillus species have the capability to fix the atmospheric nitrogen symbiotically. Nevertheless, the process of $\mathrm{SNF}$ is only limited to the legume plants ${ }^{[91]}$. While non-symbiotic nitrogen fixation ${ }^{[85]}$, mostly occurs in free living diazotrophs, (genera resembling Azoarcus ${ }^{[92]}$, Azospirillum bacterial strain ${ }^{[93]}$, Burkholderia sp. ${ }^{[94]}$, Gluconacetobacter (genus) ${ }^{[95]}$ as well as Pseudomonas $^{[96]}$. In a study, a strain of Pseudomonas fluorescens B16 (PGPR), was discovered in tomatoes roots, exhibiting the development of plant height, fruit weight as well as flower number ${ }^{[97]}$. Currently in agriculture, approximately $65 \%$ of nitrogen is produced through biological nitrogen fixation.
Legume plants show biological nitrogen fixation, that is proficient and meet its $\mathrm{N}_{2}$ requirements. A huge amount of $\mathrm{N}_{2}$ is fixed in the leguminous plants like grains, whereas soil and succeeding crops get benefited from it in root and shoot deposits. Hence leguminous plants significantly decrease the $\mathrm{N}_{2}$ requisite from the peripheral sources ${ }^{[14]}$.

The most studied and plant beneficial feature of mutual SNF is revealed in Rhizobia ${ }^{[98]}$. It can be used for improving the nitrogen fixation and evidence has proved that they are effectively colonized in the soil for several years even in the absence of the plant host ${ }^{[99]}$. Rhizobium as well as Bradyrhizobium can produce in the nodules of the root surface of legume plants like, soybean, peanut, pea as well as alfalfa, in which beneficial bacteria converts and process the nitrogen into beneficial form, could be consumed by plants as an $\mathrm{N}_{2}$ source ${ }^{[100,101]}$. However other nutrient acquirement mechanisms have been noticed which enable the plant access to macro as well as micro nutrients ${ }^{[37]}$.

The rhizobium-legume symbiosis (Rhizobium/Mesorhizobium/ Bradyrhizobium), source of $\mathrm{N}_{2}$ and an active agronomic approach that ensured the supply of $\mathrm{N}_{2}$ than the use of nitrogen fertilizer ${ }^{[102]}$. However, several environmental aspects limit the $\mathrm{N}_{2}$ fixation, for example, deficiency of soil moisture, excesses temperature, osmotic stress, acidity, salinity, insufficiency of nutrient, soil alkalinity, overdoes of fertilizers as well as pesticides; as all these aspects affect the persistence as well as infectivity of the rhizobia, which is vital for the process of nitrogen fixation ${ }^{[103]}$. Azospirillum is another free-living nitrogen fixing bacteria that might fertilize sorghum, wheat and maize. Although Azospirillum play role in $\mathrm{N}_{2}$ fixation, it is also attributed to increasing the yield, mainly increase the root development and therefore enhances the rates of water as well as mineral uptake to plants upper part ${ }^{[104]}$. Studies investigated that the strain of AM increased plant growth in numerous environmental stress ${ }^{[105]}$. Furthermore, arbuscular mycorrhizae have great potential to enhance the nodule formation, $\mathrm{N}_{2}$ fixation in the legumes ${ }^{[102]}$. Biological $\mathrm{N}_{2}$ fixation and increase in phosphorus (P) availability and other nutrients also its synergistic association to rhizosphere microorganisms may be very operative for getting the highest yield in leguminous plants. Studies in the laboratory and field atmospheres have shown that inoculation of the arbuscular mycorrhizae with biological $\mathrm{N}_{2}$ fixing bacteria was very dynamic for increasing $\mathrm{N}_{2}$ fixation in legume plants $^{[106]}$. For instance, arbuscular mycorrhizae exist in stress atmospheres, for example, salinity ${ }^{[107]}$.

In addition, associations between legume plants, rhizobacteria, and mycorrhiza have shown to be more beneficial and led to synergetic growth effects and stimulated both the phosphate (P) and nitrogen $\left(\mathrm{N}_{2}\right)$ uptake to the plants ${ }^{[108]}$. Such associations are significantly affected by environmental stresses, which severely limit the yield of leguminous crops ${ }^{[102]}$. Therefore, its association with plants may be very effective for plant growth as well as development in the stress surroundings ${ }^{[109]}$. In addition, root colonization in AM favors the nodulation by rhizobia ${ }^{[110]}$. Bisht et al. studied that AM could have revealed a positive result with $R$. leguminosarum, a similar response was noticed when $P$. fluorescens was used. This study proposed that plant growth improved with arbuscular mycorrhizae and PGP rhizobacteria depends on the type of bacterium ${ }^{[111]}$. Overall, stress is one of the limiting aspects of the $\mathrm{N}_{2}$ fixation; it could be overcome by combining the arbuscular mycorrhizae in stress soils. In addition, it will be more operative in the stress environment while using in combination with other microbial populations. The selection of 
the novel microorganisms will govern the success of this method.

\section{Do soil rhizobacteria affect the phosphate solubilization system and plant growth?}

Phosphorous is known as the second most important macronutrient for plant growth as well as development, as it participates essentially in many metabolic pathways specifically in respiration, photosynthesis cell signaling as well as macromolecules synthesis ${ }^{[112]}$. Nevertheless, it is one of the limiting nutrients for plant development. It occurs in an inorganic (bound form or labile) as well as an organic (bound form) form. When phosphorous is applied to the soil, its $90 \%-95 \%$ is reduced and inaccessible to the plants via changes to insoluble organic form (for example, phosphomono and triesters/inositol phosphate) and inorganic minerals form (phosphates of iron mostly apatite and aluminum and calcium) ${ }^{[113]}$.

The soil remains the highest source that supplied $\mathrm{P}$ to the plants ${ }^{[114]}$. The accessibility of phosphate to plants is affected by various abiotic factors as well as available soil microorganisms ${ }^{[115]}$. Low concentration of the soluble phosphate could limit plant growth $^{[116,117]}$. Phosphate fertilizer supplied the available form of phosphate to plants, too much use of it is not only expensive but also destructive to the environment ${ }^{[118]}$

P solubilizing microbes are most prevalent in rhizospheres ${ }^{[119]}$. In this case, $\mathrm{P}$ solubilizing bacteria play a key role in releasing organic phosphates to solubilize inorganic phosphate form ${ }^{[120]}$. Many researchers described the role of $\mathrm{P}$ solubilizing bacteria in plant development. Joe et al. used Acinetobacter sp. isolates of the Phyllanthus amarus, Bacillus sp. with phosphate solubilizing and salt-tolerant properties ${ }^{[121]}$. Secretion of the root exudates for example organic ligands could also modify the $\mathrm{P}$ concentration in the soil ${ }^{[122]}$. The PGPR has various influences on the soil surrounding plant roots for example phosphorous solubilization ${ }^{[123]}$.

The solubilization of $\mathrm{P}$ in the rhizosphere is a more prevalent mechanism used by PGPR that rise the nutrients available to the host plant ${ }^{[124]}$. Various $\mathrm{P}$ solubilizing microbes are recognized which change the insoluble $\mathrm{P}$ to soluble form via several mechanisms, Such as, acidification process, exudation of organic acids $^{[125]}$, also through chelation as well as exchange reactions ${ }^{[126]}$. Soil microorganisms support the release of phosphate to plants and plants only absorb the soluble form of $\mathrm{P}$ (e.g. monobasic $\left(\mathrm{H}_{2} \mathrm{PO}_{4}{ }^{-}\right)$ form, also dibasic $\left(\mathrm{H}_{2} \mathrm{PO}_{4}{ }^{2-}\right)$ form ${ }^{[14]}$.

Rhizobia, containing $R$. leguminosarum, Azotobacter, $M$. mediterraneum, Azospirillium Radyrhizobium, Bacillus japonicum $^{[14,127,128]}$, and $M$. mediterraneum has been shown to play a role in improving $\mathrm{P}$ solubilizing capability and has been studied in chickpea as well as in barley plants ${ }^{[129]}$. In addition, saprophytic bacterial strains as well as fungi are also described to show a role in soil phosphate solubilization through chelation mechanism $^{[130]}$. Even though these microorganisms solubilize the phosphorus, which improved the soil fertility, however, studies about its usage as a bio-fertilizer are rare ${ }^{[11]}$. Therefore, studies are necessary to explore the novel properties of PGPR for phosphate solubilization with mechanisms that are essential to recognize its effects on plant development.

\section{Interactions among beneficial rhizobacteria and mycorrhizae and modulating the stress}

The latest studies have shown various abiotic factors that have marked effects on plant growth and developments. Among these, soil $\mathrm{pH}$, temperature, erosion, waterlog, salinity, heavy metals, salinity, fungicides, and drought are the major factors that affect plant growth ${ }^{[131-136]}$. Therefore, its growth and yield will be affected. However, research has explored the significance of beneficial rhizobacteria as well as mycorrhizae in the growth and development of several plants in stress environments (Figure 2). This positive interaction mainly occurs among PGP rhizobacteria, mycorrhizae and plants ${ }^{[25]}$. The addition of a single bacterial inoculum might have core effects on the rhizosphere structure, but it will depend on whether the fresh inoculum was already a part of that bacterial population or not ${ }^{[137]}$. Similarly, it could be more effective when a combination of PGPR is used ${ }^{[138]}$.

Supportive effects of PGP rhizobacteria and mycorrhizae could be very useful for plant growth in many ways. In mixture inoculation, these strains not only participate effectively to the rhizosphere population, nevertheless, it also illustrates suitable interactions for the growth of both symbionts. For example, the development of mycorrhizae through PGP rhizobacteria is because of its root's colonization and nutrients uptake ${ }^{[125]}$. In the same way, the rise in the root exudates by the microbes triggers the fungus growth and hence increases the rate of root colonization ${ }^{[89]}$. The study by Watts-Williams, et al. showed the effects of AM on plant growth. The authors studied and about 20 various Medicago truncatula assents were inoculated with arbuscular mycorrhiza (Funneliformis mosseae), a various response in plant physiology, as well as gene expression, were noticed among the assents ${ }^{[139]}$. Studying the $P$. fluorescens C7R12, it was shown as an operative bio-control mediator in comparison to the Fusarium species. Furthermore, it is useful for supporting the relationship between Medicago truncatula and G. mossea $e^{[140]}$. In a study ${ }^{[141]}$, authors recognized the capability of the Pseudomonas specie to produce the antifungal metabolites but these metabolites did not cause any adverse result on $G$. mosseae. In response, it supports roots colonization via hyphae. Bianciotto et al. identified the synthesis of exopolysaccharides (EPSs) from rhizobia, which improved the attachment of bacterial strain to mycorrhizae structure ${ }^{[142]}$. Thus, the combination of the rhizobacteria can rise the activity of arbuscular mycorrhizae in the symbiotic association ${ }^{[143]}$. The occurrence of PGP rhizobacteria, as well as mycorrhizae in the rhizosphere, can encourage the growth of fungus hyphae via enhancing cell permeability, help the roots in penetration to fungus ${ }^{[144]}$, and fungus hyphae can rise the activities of bacterial strains, which solubilize the phosphorus ${ }^{[145]}$. Such associations are significantly affected by environmental stresses, which severely limit the yield of leguminous crops $^{[102]}$. PGP rhizobacteria, mycorrhizal strains both in alone and in combination could be suitable for ameliorating the plant growth both in normal and in stressful situations. Nevertheless, commercially beneficial inoculants show variable performance. Indefinite conditions, these strain fails to procedure the symbiotic association as detected by ${ }^{[146]}$. Studies also presented that the failure in the performance might be due to less proficiency of the inoculants to native microbial populations as well as bacterial activity in the rhizosphere largely influenced via competition to native microbial populations for nutriment and niche ${ }^{[147]}$.

Recently a study has shown that the central cause of fewer yields can be due to less performance of bacteria in the rhizosphere, which may be due to the unsuitability of the inoculated bacterial species to those already existing sp. in the rhizosphere. In certain circumstances, the inoculated bacteria matched the original bacterial population, benefits to the plant growth, whereas 
frequently it did not work beneficially to plants. Therefore, the consideration of the size inequality using the microbial soil enhancements must be an essential part of the experiment. Because it will inform about the synthesis of more effective microbial end products and ensure the use of a combination of useful microbes (PGPR) into supportable and uniform yield production ${ }^{[148]}$. Likewise, nutrients in the soil also disturb the activities of mycorrhizae. For example, activities of AM decreased due to a large amount of $\mathrm{P}$ concentration in the soil ${ }^{[149]}$. Such limitations arise when a single bacterial strain is used. But, strain in the mixture can reduce these unpredictable outcomes. In addition, there could be a condition occurs where deleterious associations arise when a bacterium in the symbiosis is not specific or a member of the relationship is pathogenic ${ }^{[150]}$. Hence, to get the highest benefits from these beneficial microbial populations, it is needed to define the specificity of the bacterial as well as fungus strains for the plant. Moreover, strains in combination might illustrate more consistent performance. Summary of some experimental studies showing the importance of rhizobia in the plant growth in stress environments is shown in Table 1.

Table 1 Role of the PGP Rhizobacteria in plant growth and development in stress conditions

\begin{tabular}{|c|c|c|c|c|}
\hline Crop species & Bacterial species/strain & Stress category & Response & References \\
\hline Tomato & Achromobacter piechaudii ARV8 & Salinity & Strains improved fresh and dry weight and water proficiency & [151] \\
\hline Mustard & Rhodococcus species & Heavy metals & $\begin{array}{l}\text { It keeps the plant from the metal toxicity as well as essential progress to } \\
\text { the plant was identified }\end{array}$ & [152] \\
\hline chickpea & Mesorhizobium species & $\begin{array}{l}\mathrm{pH} \text { value and } \\
\text { temperature }\end{array}$ & $\begin{array}{l}\text { Isolate was diverse in growth at different } \mathrm{pH} \text { and strains also showed } \\
\text { more tolerance to the temperature }\end{array}$ & [128] \\
\hline Retama & $\begin{array}{l}\text { B. thuringiensis, } \\
\text { Glomus intraradices }\end{array}$ & Drought & $\begin{array}{l}\text { Enhanced the growth of root, less water required to yield and shoot } \\
\text { biomass }\end{array}$ & [153] \\
\hline $\begin{array}{c}\text { Maize } \\
\text { (Zea mays/corn) }\end{array}$ & $\begin{array}{l}\text { E. aerogenes, Flavobactrium } \\
\text { ferrugineum }\end{array}$ & Salinity & $\begin{array}{l}\text { Increase water and chlorophyll contents and } \mathrm{Na}+/ \mathrm{K}+\text { proportion was } \\
\text { identified in inoculated other than un-inoculated one }\end{array}$ & [154] \\
\hline Kidney bean & $\begin{array}{l}\text { R. tropici co-inoculated with } \\
\text { Paenibacillus polymyxa }\end{array}$ & Drought & Enhanced plant height, dry weight, and shoots and nodule number & [155] \\
\hline Chickpea & M. ciceri, $M$. mediterraneum & Salt resistant & Sustain the plant growth and nitrogen $\left(\mathrm{N}_{2}\right)$ fixation & [156] \\
\hline Pea & Rhizobium MRP1 & Herbicides & $\begin{array}{l}\text { Enhanced the biomass, leghemoglobin contents, nodulation, roots and } \\
\text { shoots (P\&N), and seeds production }\end{array}$ & {$[157,158]$} \\
\hline Tomato & $\begin{array}{l}\text { P. fluorescens, P. stutzeri and } \\
\text { P. aeruginosa }\end{array}$ & Salinity & Improved roots as well as shoots development & [46] \\
\hline Pea & Rhizobium MRP1 & Fungicides & $\begin{array}{l}\text { Enhanced the biomass, leghemoglobin contents, nodulation, shoot (P \& } \\
\mathrm{N} \text { ), seed production }\end{array}$ & [159] \\
\hline Wheat & $\begin{array}{l}\text { Bacillus species Enterobacter } \\
\text { species and Paenibacillus species }\end{array}$ & Salinity & Produce more mass as compared to the control one & [160] \\
\hline Lentil & Rhizobium RL9 & Heavy metals & $\begin{array}{l}\text { Improved growth of chlorophyll, } \mathrm{N}_{2} \text {, seed protein and seed production } \\
\text { and nodulation }\end{array}$ & {$[161,162]$} \\
\hline $\begin{array}{c}\text { Maize } \\
\text { (Zea mays/corn) }\end{array}$ & $\begin{array}{l}\text { Glomus mosseae, } \\
\text { Acaulospora laevis }\end{array}$ & Heavy metals & Developed the shoots length and roots shoot biomass & [105] \\
\hline Lentil & Rhizobia & Salts/osmotic & Enhanced biomass, dry weight and nodule formation & [163] \\
\hline $\begin{array}{c}\text { Salicornia } \\
\text { ramosissima }\end{array}$ & Rhizobacteria consortia & $\begin{array}{l}\text { Salinity/CO } \mathrm{CO}_{2} \\
\text { /temperature }\end{array}$ & Improved the germination Salicornia ramosissima seeds & [164] \\
\hline $\begin{array}{l}\text { Glycyrrhiza } \\
\text { (licorice) }\end{array}$ & $\begin{array}{l}\text { Rhizobacteia and arbuscular } \\
\text { mycorrhizal }\end{array}$ & Drought & improved the plant growth and biomass of many legume plants & [20] \\
\hline
\end{tabular}

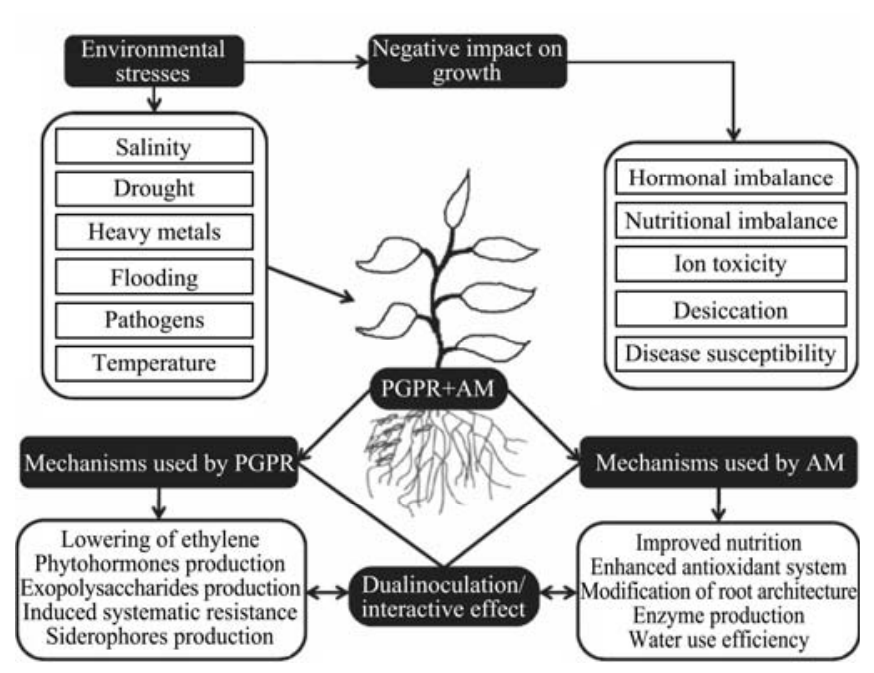

Figure 2 Potential mechanisms used by PGP Rhizobacteria \& mycorrhizae (AM) for improving the plant growth under stress circumstance $^{[165]}$

\section{Conclusions}

The rhizosphere is a distinctive niche that provides residence and nourishment to microbes. Such microorganisms produce diverse benefits such as encourage the plant growth, resistance to diseases and existence in stressful circumstances with many other anonymous benefits. Enormous studies have concerted on the potential for an individual microbial strain to give maximum benefits to the plants and it is furthermore apparent that microbes could act symbiotically to influence plant health, development as well as abiotic factors. Multiple interactions that cause such association and persistence of the root microbiome are exceptionally confusing and not clear. Genetically modified PGP rhizobacteria can increase plant development much better than the normal $\mathrm{PGPR}^{[10]}$. It is suggested that more research should be done on beneficial rhizospheric microorganisms and its interactions with each other and plant hosts, to determine how to shape them more competent for plant health and incessant yield production ${ }^{[44]}$. However, complete information on the identifying techniques and assortment of the novel rhizobia for the rhizosphere competency to 
increase the field level success is required to explore. In order to improve knowledge of PGPR study to a more advanced level, it might be essential to choose and document the genetic as well as molecular mechanisms used in such beneficial interactions. Further a well understanding of how the beneficial rhizobia and its molecules are influencing the plant growth will allow effective progress of rhizobacterial importance in the field ${ }^{[37]}$. Subsequently, a comprehensive study to benefits from the potential PGPR could offer development of current research and can develop plant growth, sustainability, and finally will raise the agriculture products. Overall by the progress of culture-independent approaches 'omics' as well as bioinformatics methods can deeper understand the beneficial aspects of rhizosphere microbes and its effects on plant growth.

\section{Acknowledgements}

The authors acknowledge that this work was financially supported by the Fundamental Research Fund for the Central Universities of China (Project No. lzujbky-2017-k15).

\section{[References]}

[1] Hiltner L. Über neuere Erfahrungen und Probleme auf dem Gebiete der Bodenbakteriologie unter besonderer Berücksichtigung der Gründüngung und Brache. Arb DLG, 1904; 98: 59-78.

[2] Burdman S, Jurkevitch E, Okon Y J, Subba Rao N S, Dommerguers Y R. Recent advances in the use of plant growth promoting rhizobacteria (PGPR) in agriculture. Forestry, 2000; 2: 229-250.

[3] Qin J, Li R, Raes J, Arumugam M, Burgdorf K S, Manichanh C, et al. A human gut microbial gene catalogue established by metagenomic sequencing. Nature, 2010; 464: 59-65.

[4] Gevers D, Knight R, Petrosino J F, Huang K, McGuire A L, Birren B W, et al. The human microbiome project: A community resource for the healthy human microbiome. PLoS Biology, 2012; 10(8): e1001377.

[5] Raaijmakers J M, Paulitz T C, Steinberg C, Alabouvette C, Moënne-Loccoz Y. The rhizosphere: a playground and battlefield for soilborne pathogens and beneficial microorganisms. Plant and Soil, 2009; 321(1-2): 341-361.

[6] Berendsen R L, Pieterse C M, Bakker P A. The rhizosphere microbiome and plant health. Trends in Plant Science, 2012; 17(8): 478-486.

[7] Bringhurst R M, Cardon Z G, Gage D J. Galactosides in the rhizosphere: Utilization by Sinorhizobium meliloti and development of a biosensor. PNAS, 2001; 98: 4540-4545.

[8] Kumar A, Vandana R S, Singh M, Pandey K D. A promising approach for disease management. Microbes and Environmental Management. In: Plant growth promoting rhizobacteria (PGPR). Lap Lambert Academic Publishing. 2015; pp.191-205.

[9] Vejan P, Abdullah R, Khadiran T, Ismail S, Boyce, A N. Role of plant growth promoting rhizobacteria in agricultural sustainability-a review. Molecules, 2016; 21(5): 573. doi: 10.3390/molecules21050573.

[10] Ojuederie O B, Olanrewaju O S, Babalola O O. Plant growth promoting rhizobacterial mitigation of drought stress in crop plants: Implications for sustainable agriculture. Agronomy, 2019; 9: 712 . doi: 10.3390/agronomy9110712.

[11] Gouda S, Kerry R G, Das G, Paramithiotis S, Shin H S, Patra J K. Revitalization of plant growth promoting rhizobacteria for sustainable development in agriculture. Microbiological Research, 2018; 206: 131-140.

[12] Montesinos, E. Plant-associated microorganisms: A view from the scope of microbiology. International Microbiology, 2003; 6(4): 221-223.

[13] Benizri E, Baudoin E, Guckert A. Root colonization by inoculated plant growth-promoting rhizobacteria. Biocontrol Science and Technology, 2001; 11(5): 557-574.

[14] Bhattacharyya P N, Jha D K. Plant growth-promoting rhizobacteria (PGPR): emergence in agriculture. World Journal of Microbiology and Biotechnology, 2012; 28: 1327-1350.

[15] Liu X B, Etienne R S, Liang M X, Wang Y F, Yu S X. Experimental evidence for an intraspecific Janzen-Connell effect mediated by soil biota. Ecology, 2015; 96(3): 662-671.
[16] Babalola O O. Beneficial bacteria of agricultural importance. Biotechnology Letters, 2010; 32(11): 1559-1570.

[17] Bever J D, Platt T G, Morton E R J. Microbial population and community dynamics on plant roots and their feedbacks on plant communities. Annual Review of Microbiology, 2012; 66: 265-283.

[18] Kumar A, Verma H, Yadav A, Ansari W A, Singh P P, Singh S K, et al. Plant Growth Promoting Rhizobacteria of Curcuma amada (Mango ginger). Journal of Pure and Applied Microbiology, 2017; 11: 513-520.

[19] Mendes R, Garbeva P, Raaijmakers J M. The rhizosphere microbiome: significance of plant beneficial, plant pathogenic, and human pathogenic microorganisms. FEMS Microbiology Reviews, 2013; 37: 634-663.

[20] Hao Z P, Xie W, Jiang X L, Wu Z X, Zhang X, Chen B D. Arbuscular mycorrhizal fungus improves rhizobium-glycyrrhiza seedling symbiosis under drought stress. Agronomy, 2019; 9: 572. doi 10.3390/agronomy9100572.

[21] Torsvik V, Ovreas L, Thingstad T F. Prokaryotic diversity--magnitude, dynamics, and controlling factors. Science, 2002; 296: 1064-1066.

[22] Gans J, Wolinsky M, Dunbar J. Computational improvements reveal great bacterial diversity and high metal toxicity in soil. Science, 2005; 309: 1387-1390.

[23] Turner T R, James E K, Poole P S. The plant microbiome. Genome Biology, 2013; 14(6): 209. doi: 10.1186/gb-2013-14-6-209.

[24] Schlaeppi K, Bulgarelli D. The plant microbiome at work. Molecular Plant-Microbe Interactions, 2015; 28(3): 212-217.

[25] Hawkes C V, DeAngelis K M, Firestone M K. Root interactions with soil microbial communities and processes. The Rhizosphere (An Ecological Perspective). Elsevier, 2007; pp. 1-29.

[26] DeAngelis K M, Ji P, Firestone M K, Lindow S E. Two novel bacterial biosensors for detection of nitrate availability in the rhizosphere. Applied and Environmental Microbiology, 2005; 71: 8537-8547.

[27] Uroz S, Oger P, Morin E, Frey-Klett P. Distinct ectomycorrhizospheres share similar bacterial communities as revealed by pyrosequencing-based analysis of 16S rRNA genes. Applied and Environmental Microbiology, 2012; 78: 3020-3024

[28] Olanrewaju O S, Glick B R, Babalola O O. Mechanisms of action of plant growth promoting bacteria. World J Microbiol Biotechnol, 2017; 33(11): 197. doi: 10.1007/s11274-017-2364-9.

[29] Kloepper J W, Schroth M N. Plant growth-promoting rhizobacteria on radishes. In: Proceedings of Proc. of the 4th Internet. Conf. on Plant Pathogenic Bacter, Station de Pathologie Vegetale et Phytobacteriologie, INRA, Angers France, 1978; pp. 879-882.

[30] Doornbos R F, van Loon L C, Bakker H M. Impact of root exudates and plant defense signaling on bacterial communities in the rhizosphere. A review. Agronomy for Sustainable Development, 2012; 32: 227-243.

[31] Phillips R P, Finzi A C, Bernhardt E S. Enhanced root exudation induces microbial feedbacks to $\mathrm{N}$ cycling in a pine forest under long-term $\mathrm{CO}_{2}$ fumigation. Ecology Letters, 2011; 14(2): 187-194.

[32] Glick B R, Cheng Z, Czarny J, Duan J. Promotion of plant growth by ACC deaminase-producing soil bacteria. Eur J Plant Pathol, 2007; 119: 329-339.

[33] Nadeem S M, Zahir Z A, Naveed M, Ashraf M. Microbial ACC-deaminase: prospects and applications for inducing salt tolerance in plants. Critical Reviews in Plant Sciences, 2010; 29: 360-393.

[34] Berg G. Plant-microbe interactions promoting plant growth and health: perspectives for controlled use of microorganisms in agriculture. Applied Microbiology and Biotechnology, 2009; 84: 11-18.

[35] Hayat R, Ali S, Amara U, Khalid R, Ahmed I. Soil beneficial bacteria and their role in plant growth promotion: A review. Annals of Microbiology 2010; 60: 579-598.

[36] Danish S, Zafar-ul-Hye M, Mohsin F, Hussain M. ACC-deaminase producing plant growth promoting rhizobacteria and biochar mitigate adverse effects of drought stress on maize growth. PLoS ONE, 2020; 15(4): e0230615. doi: 10.1371/journal.pone.0230615.

[37] Rosier A, Medeiros F H, Bais H P. Defining plant growth promoting rhizobacteria molecular and biochemical networks in beneficial plant-microbe interactions. Plant and Soil, 2018; 428: 35-55.

[38] Friesen M L, Porter S S, Stark S C, von Wettberg E J, Sachs J L, Martinez-Romero E. Microbially mediated plant functional traits. Annual Review of Ecology, Evolution, and Systematics, 2011; 42(1): $23-46$.

[39] Dessaux Y, Grandclément C, Faure D. Engineering the rhizosphere. Trends in Plant Science, 2016; 21(3): 266-278.

[40] Castrillo G, Teixeira P J P L, Paredes S H, Law T F, de Lorenzo L, Feltcher $\mathrm{M} \mathrm{E}$, et al. Root microbiota drive direct integration of 
phosphate stress and immunity. Nature, 2017; 543(7646): 513. doi: 10.1038/nature21417.

[41] Trapet P, Avoscan L, Klinguer A, Pateyron S, Citerne S, Chervin C, et al. The Pseudomonas fluorescens siderophore pyoverdine weakens Arabidopsis thaliana defense in favor of growth in iron-deficient conditions. Plant Physiology, 2016; 171(1): 675-693.

[42] Zhou C, Guo J, Zhu L, Xiao X, Xie Y, Zhu J, et al. Paenibacillus polymyxa BFKC01 enhances plant iron absorption via improved root systems and activated iron acquisition mechanisms. Plant Physiology and Biochemistry, 2016; 105: 162-173.

[43] Miransari M, Bahrami H, Rejali F, Malakouti M. Effects of soil compaction and arbuscular mycorrhiza on corn (Zea mays L.) nutrient uptake. Soil and Tillage Research, 2009; 103(2): 282-290.

[44] Mustafa S, Kabir S, Shabbir U, Batool R. Plant growth promoting rhizobacteria in sustainable agriculture: from theoretical to pragmatic approach. Symbiosis, 2019; 78: 115-123.

[45] Zahir Z A, Arshad M, Frankenberger W T. Plant growth promoting rhizobacteria: applications and perspectives in agriculture. Advances in Agronomy, 2004; 81(1): 98-169.

[46] Tank N, Saraf M. Salinity-resistant plant growth promoting rhizobacteria ameliorates sodium chloride stress on tomato plants. Journal of Plant Interactions, 2010; 5: 51-58.

[47] Heidari M, Golpayegani A. Effects of water stress and inoculation with plant growth, promoting rhizobacteria (PGPR) on antioxidant status and photosynthetic pigments in basil, (Ocimum basilicum L.). Journal of the Saudi Society of Agricultural Sciences, 2012; 11(1): 57-61.

[48] Gamalero E, Berta G, Glick B R. The use of microorganisms to facilitate the growth of plants in saline soils. In: Khan M, Zaidi A, Musarrat J (Ed.). Microbial strategies for crop improvement. Berlin, Heidelberg: Springer. 2009; pp.1-22.

[49] Glick B. R, Bashan Y. Genetic manipulation of plant growth-promoting bacteria to enhance biocontrol of phytopathogens. Biotechnology Advances, 1997; 15(2): 353-378.

[50] Persello-Cartieaux F, Nussaume L, Robaglia C. Tales from the underground: molecular plant-rhizobacteria interactions. Plant, Cell \& Environment, 2003; 26(2): 189-199.

[51] Patten C L, Glick B R. Role of Pseudomonas putida indoleacetic acid in development of the host plant root system. Applied and Environmental Microbiology, 2002; 68(8): 3795-3801.

[52] Ashraf M, Hasnain S, Berge O, Mahmood T. Inoculating wheat seedlings with exopolysaccharide-producing bacteria restricts sodium uptake and stimulates plant growth under salt stress. Biology and Fertility of Soils, 2004; 40(3): 157-162.

[53] Sandhya V, Grover M, Reddy G, Venkateswarlu B. Alleviation of drought stress effects in sunflower seedlings by the exopolysaccharides producing Pseudomonas putida strain GAP-P45. Biology and Fertility of Soils, 2009; 46(1): 17-26.

[54] Gamalero E, Berta G, Massa N, Glick B, Lingua G. Interactions between Pseudomonas putida UW4 and Gigaspora rosea BEG9 and their consequences for the growth of cucumber under salt-stress conditions. Journal of Applied Microbiology, 2010; 108(1): 236-245.

[55] Christie P, Li X, Chen B. Arbuscular mycorrhiza can depress translocation of zinc to shoots of host plants in soils moderately polluted with zinc. Plant and Soil, 2004; 261: 209-217.

[56] Willis A, Rodrigues B, Harris P. The ecology of arbuscular mycorrhizal fungi. Critical Reviews in Plant Sciences, 2013; 32: 1-20.

[57] Giovannetti M, Avio L, Fortuna P, Pellegrino E, Sbrana C, Strani P. At the root of the wood wide web: Self recognition and nonself incompatibility in mycorrhizal networks. Plant Signaling \& Behavior, 2006; 1: 1-5.

[58] Oueslati, O. Allelopathy in two durum wheat (Triticum durum L.) varieties. Agriculture, ecosystems \& environment, 2003; 96: 161-163.

[59] McArthur D A, Knowles N R. Influence of species of vesicular-arbuscular mycorrhizal fungi and phosphorus nutrition on growth, development, and mineral nutrition of potato (Solanum tuberosum L.). Plant Physiology, 1993; 102: 771-782.

[60] Sharda J, Koide R. Exploring the role of root anatomy in P-mediated control of colonization by arbuscular mycorrhizal fungi. Botany, 2010; 88: $165-173$.

[61] Singh P K. Role of glomalin related soil protein produced by arbuscular mycorrhizal fungi: a review. Agric Sci Res J, 2012; 2(3): 119-125.

[62] Gadkar V, Rillig M C. The arbuscular mycorrhizal fungal protein glomalin is a putative homolog of heat shock protein 60 . FEMS
Microbiology Letters, 2006; 263: 93-101.

[63] Rillig M C, Maestre F T, Lamit L J. Microsite differences in fungal hyphal length, glomalin, and soil aggregate stability in semiarid Mediterranean steppes. Soil Biology and Biochemistry, 2003; 35: 1257-1260.

[64] Bethlenfalvay G, Linderman R. Mycorrhizae in Sustainable Agriculture. American Society of Agronomy, Madison, Wisconsin. ASA special publication, 1992; 54.

[65] Rillig M C, Mummey D L. Mycorrhizas and soil structure. New Phytologist, 2006; 171: 41-53.

[66] Shokri S, Maadi B. Effects of arbuscular mycorrhizal fungus on the mineral nutrition and yield of Trifolium alexandrinum plants under salinity stress. J Agron, 2009; 8: 79-83.

[67] Wu Q, Li G, Zou Y. Roles of arbuscular mycorrhizal fungi on growth and nutrient acquisition of peach (Prunus persica L. Batsch) seedlings. J Anim Plant Sci, 2011; 21: 746-750.

[68] Marschner H, Dell B. Nutrient uptake in mycorrhizal symbiosis. Plant and Soil, 1994; 159: 89-102.

[69] Meding S, Zasoski R. Hyphal-mediated transfer of nitrate, arsenic, cesium, rubidium, and strontium between arbuscular mycorrhizal forbs and grasses from a California oak woodland. Soil Biology and Biochemistry, 2008; 40: 126-134.

[70] Nkwine C, Zake J Y. Effect of soybean-maize cropping rotation on soybean rhizobial population and soybean nodulation. MS dissertation. Kampala: Makerere University, 1990; 99 p.

[71] Herschkovitz Y, Lerner A, Davidov Y, Rothballer M, Hartmann A, Okon $\mathrm{Y}$, et al. Inoculation with the plant-growth-promoting rhizobacterium Azospirillum brasilense causes little disturbance in the rhizosphere and rhizoplane of maize (Zea mays). Microbial Ecology, 2005; 50: 277-288.

[72] McCully M E. Niches for bacterial endophytes in crop plants: a plant biologist's view. Functional Plant Biology, 2001; 28: 983-990.

[73] Dakora F D, Phillips D A. Root exudates as mediators of mineral acquisition in low-nutrient environments. In Food Security in Nutrient-Stressed Environments: Exploiting Plants' Genetic Capabilities. Springer, 2002; pp.201-213.

[74] Rudrappa T, Biedrzycki M L, Kunjeti S G, Donofrio N M, Czymmek K J, Paul W P, et al. The rhizobacterial elicitor acetoin induces systemic resistance in Arabidopsis thaliana. Communicative \& Integrative Biology 2010; 3: 130-138.

[75] Hayat S, Faraz A, Faizan M. Root exudates: Composition and impact on plant-microbe interaction. In: Biofilms in Plant and Soil Health. John Wiley \& Sons Ltd, 2017; pp.179-193.

[76] Finkel O M, Castrillo G, Paredes S H, González I S, Dangl J L. Understanding and exploiting plant beneficial microbes. Current Opinion in Plant Biology, 2017; 38: 155-163.

[77] Matilla M A, Espinosa-Urgel M, Rodríguez-Herva J J, Ramos J L, Ramos-González M I. Genomic analysis reveals the major driving forces of bacterial life in the rhizosphere. Genome biology, 2007; 8: 179. doi: 10.1186/gb-2007-8-9-r179.

[78] Bais H P, Weir T L, Perry L G, Gilroy S, Vivanco J M. The role of root exudates in rhizosphere interactions with plants and other organisms. Annu. Rev. Plant Biol, 2006; 57: 233-266.

[79] Simon H M, Jahn C E, Bergerud L T, Sliwinski M K, Weimer P J, Willis $\mathrm{D} \mathrm{K}$, et al. Cultivation of mesophilic soil crenarchaeotes in enrichment cultures from plant roots. Appl Environ Microbiol, 2005; 71: 4751-4760.

[80] Kowalchuk G A, Buma D S, de Boer W, Klinkhamer P G, van Veen J A. Effects of above-ground plant species composition and diversity on the diversity of soil-borne microorganisms. Antonie Van Leeuwenhoek, 2002; 81(1-4): 509-520.

[81] Eberl L, Molin S, Givskov M. Surface motility of Serratia liquefaciens MG1. Journal of Bacteriology, 1999; 181: 1703-1712.

[82] Martínez-Granero F, Rivilla R, Martín M. Rhizosphere selection of highly motile phenotypic variants of Pseudomonas fluorescens with enhanced competitive colonization ability. Appl Environ Microbiol, 2006; 72: 3429-3434.

[83] Tucker S L, Talbot N J. Surface attachment and pre-penetration stage development by plant pathogenic fungi. Annual Review of Phytopathology 2001; 39: 385-417.

[84] Jones K M, Kobayashi H, Davies B W, Taga M E, Walker G C. How rhizobial symbionts invade plants: the Sinorhizobium-Medicago model. Nature Reviews Microbiology, 2007; 5(8): 619-633.

[85] Ahemad M, Kibret M. Mechanisms and applications of plant growth promoting rhizobacteria: current perspective. Journal of King saud 
University-science, 2014; 26: 1-20.

[86] Kuan K B, Othman R, Rahim K A, Shamsuddin Z H. Plant growth-promoting rhizobacteria inoculation to enhance vegetative growth, nitrogen fixation and nitrogen remobilisation of maize under greenhouse conditions. Plos One, 2016; 11(3): e0152478. doi: 10.1371/journal.pone.0152478.

[87] Damam M, Kaloori K, Gaddam B, Kausar R. Plant growth promoting substances (phytohormones) produced by rhizobacterial strains isolated from the rhizosphere of medicinal plants. International Journal of Pharmaceutical Sciences Review and Research, 2016; 37: 130-136.

[88] Riggs P J, Chelius M K, Iniguez A L, Kaeppler S M, Triplett E W. Enhanced maize productivity by inoculation with diazotrophic bacteria. Functional Plant Biology, 2001; 28: 829-836.

[89] Barea J-M, Pozo M J, Azcon R, Azcon-Aguilar C. Microbial co-operation in the rhizosphere. Journal of Experimental Botany, 2005; 56: $1761-1778$.

[90] Esitken A, Pirlak L, Turan M, Sahin F. Effects of floral and foliar application of plant growth promoting rhizobacteria (PGPR) on yield, growth and nutrition of sweet cherry. Scientia Horticulturae, 2006; 110: 324-327.

[91] Laranjo M, Alexandre, A, Oliveira S. Legume growth-promoting rhizobia: an overview on the Mesorhizobium genus. Microbiological Research, 2014; 169: 2-17.

[92] Reinhold-Hurek B, Hurek T, Gillis M, Hoste B, Vancanneyt M, Kersters $\mathrm{K}$, et al. Nitrogen-fixing proteobacteria associated with roots of Kallar grass (Leptochloa fusca (L.) Kunth), and description of two species, Azoarcus indigens sp. nov. and Azoarcus communis sp. nov. International Journal of Systematic and Evolutionary Microbiology, 1993; 43: 574-584.

[93] Bashan Y, De-Bashan L E. How the plant growth-promoting bacterium Azospirillum promotes plant growth-a critical assessment. Advances in Agronomy, Elsevier, 2010; 108: 77-136.

[94] Estrada-De Los Santos P, Bustillos-Cristales R O, Caballero-Mellado J. Burkholderia, a genus rich in plant-associated nitrogen fixers with wide environmental and geographic distribution. Appl Environ Microbiol, 2001; 67: 2790-2798.

[95] Fuentes-Ramírez L E, Bustillos-Cristales R, Tapia-Hernández A, Jiménez-Salgado T, Wang E T, Martínez-Romero E, et al. Novel nitrogen-fixing acetic acid bacteria, Gluconacetobacter johannae sp. nov. and Gluconacetobacter azotocaptans sp. nov., associated with coffee plants. International Journal of Systematic and Evolutionary Microbiology, 2001; 51: 1305-1314.

[96] Mirza M S, Mehnaz S, Normand P, Prigent-Combaret C, Moënne-Loccoz $\mathrm{Y}$, Bally R, et al. Molecular characterization and PCR detection of a nitrogen-fixing Pseudomonas strain promoting rice growth. Biology and Fertility of Soils, 2006; 43: 163-170.

[97] Minorsky P V. On the inside. Plant Physiology, 2008; 146: 1020-1021.

[98] Udvardi M, Poole P S. Transport and metabolism in legume-rhizobia symbioses. Annual Review of Plant Biology, 2013; 64: 781-805.

[99] Sanginga N, Danso S, Mulongoy K, Ojeifo A. Persistence and recovery of introduced Rhizobium ten years after inoculation on Leucaena leucocephala grown on an Alfisol in southwestern Nigeria. Plant and Soil, 1994; 159: 199-204.

[100] Van R P, Vanderleyden J. The Rhizobium-plant symbiosis. Microbiol Rev, 1995; 59(1): 124-142.

[101] Gil-Díez P, Tejada-Jiménez M, León-Mediavilla, Javier W, Jiangqi M, Kirankumar S. MtMOT1.2 is responsible for molybdate supply to Medicago truncatula nodules. Journal of Plant Cell, 2019; 42(1): 310-320.

[102] Foyer C H, Nguyen H, Lam H M. Legumes-The art and science of environmentally sustainable agriculture. Plant, Cell \& Environment, 2019; 42: 1-5.

[103] Zahran H H. Rhizobium-legume symbiosis and nitrogen fixation under severe conditions and in an arid climate. Microbiol Mol Biol Rev, 1999; 63: 968-989.

[104] Okon Y, Bloemberg G V, Lugtenberg B J. Biotechnology of biofertilization and phytostimulation. Agricultural Biotechnology, 1998; 327: 349p.

[105] Abdelmoneim T, Almaghrabi O. Improved tolerance of maize plants to heavy metals stress by inoculation with arbuscular mycorrhizal fungi. Archives des Sciences 2013; 66: 155-167.

[106] Lesueur D, Sarr A. Effects of single and dual inoculation with selected microsymbionts (rhizobia and arbuscular mycorrhizal fungi) on field growth and nitrogen fixation of Calliandra calothyrsus Meissn. Agroforestry Systems, 2008; 73: 37-45.

[107] Evelin H, Kapoor R, Giri B. Arbuscular mycorrhizal fungi in alleviation of salt stress: A review. Annals of Botany, 2009; 104: 1263-1280.

[108] Kafle A, Garcia K, Wang X, Pfeffer P E, Strahan G D, Bücking H. Nutrient demand and fungal access to resources control the carbon allocation to the symbiotic partners in tripartite interactions of Medicago truncatula. Plant Cell Environ, 2019; 42: 270-284.

[109] Farahani A, Lebaschi H, Hussein M, Hussein S A, Reza V A, Jahanfar D. Effects of arbuscular mycorrhizal fungi, different levels of phosphorus and drought stress on water use efficiency, relative water content and proline accumulation rate of Coriander (Coriandrum sativum L.). Journal of Medicinal Plants Research, 2013; 2: 125-131.

[110] Smith S, Nicholas D, Smith F. Effect of early mycorrhizal infection on nodulation and nitrogen fixation in Trifolium subterraneum L. Functional Plant Biology, 1979; 6: 305-316.

[111] Bisht R, Chaturvedi S, Srivastava R, Sharma A, Johri B. Effect of arbuscular mycorrhizal fungi, Pseudomonas fluorescens and Rhizobium leguminosarum on the growth and nutrient status of Dalbergia sissoo Roxb. Tropical Ecology, 2009; 50(2): 231-242.

[112] Khan M S, Zaidi A, Ahemad M, Oves M, Wani P A. Plant growth promotion by phosphate solubilizing fungi-current perspective. Archives of Agronomy and Soil Science, 2010; 56: 73-98.

[113] Pandey P, Maheshwari D. Two-species microbial consortium for growth promotion of Cajanus cajan. Current Science, 2007; 92(8): 1137-1142.

[114] Sharma P, Padh H, Shrivastava N. Hairy root cultures: a suitable biological system for studying secondary metabolic pathways in plants. Engineering in Life Sciences, 2013; 13: 62-75.

[115] Buol S W, Eswaran H. Oxisols. In Advances in Agronomy, 1999; 68 : 151-195.

[116] Antoun H. Beneficial microorganisms for the sustainable use of phosphates in agriculture. Procedia Engineering, 2012; 46: 62-67.

[117] Wang D, Lv S, Jiang P, Li Y. Roles, regulation, and agricultural application of plant phosphate transporters. Frontiers in Plant Science, 2017; 8: 817. doi: 10.3389/fpls.2017.00817.

[118] Zou X, Binkley D, Doxtader K G. A new method for estimating gross phosphorus mineralization and immobilization rates in soils. Plant and Soil, 1992; 147: 243-250.

[119] Vázquez M M, César S, Azcón R, Barea J M. Interactions between arbuscular mycorrhizal fungi and other microbial inoculants (Azospirillum, Pseudomonas, Trichoderma) and their effects on microbial population and enzyme activities in the rhizosphere of maize plants. Applied Soil Ecology, 2000; 15: 261-272.

[120] Otieno N, Lally R D, Kiwanuka S, Lloyd A, Ryan D, Germaine K J, et al. Plant growth promotion induced by phosphate solubilizing endophytic Pseudomonas isolates. Frontiers in Microbiology, 2015; 6: 745. doi: 10.3389/fmicb.2015.00745.

[121] Joe M M, Devaraj S, Benson A, Sa T. Isolation of phosphate solubilizing endophytic bacteria from Phyllanthus amarus Schum \& Thonn: Evaluation of plant growth promotion and antioxidant activity under salt stress. Journal of Applied Research on Medicinal and Aromatic plants, 2016; 3: 71-77.

[122] Hinsinger P. Bioavailability of soil inorganic $P$ in the rhizosphere as affected by root-induced chemical changes: a review. Plant and Soil, 2001; 237: 173-195

[123] Alori E T, Glick B R, Babalola O O. Microbial phosphorus solubilization and its potential for use in sustainable agriculture. Frontiers in microbiology, 2017; 8: 971. doi: 10.3389/fmicb.2017.00971.

[124] Richardson A E. Prospects for using soil microorganisms to improve the acquisition of phosphorus by plants. Functional Plant Biology, 2001; 28: 897-906.

[125] Richardson A E, Barea J-M, McNeill A M, Prigent-Combaret C. Acquisition of phosphorus and nitrogen in the rhizosphere and plant growth promotion by microorganisms. Plant and Soil, 2009; 321: 305-339.

[126] Hameeda B, Harini G, Rupela O, Wani S, Reddy G. Growth promotion of maize by phosphate-solubilizing bacteria isolated from composts and macrofauna. Microbiological Research, 2008; 163: 234-242.

[127] Afzal A, Bano A. Rhizobium and phosphate solubilizing bacteria improve the yield and phosphorus uptake in wheat (Triticum aestivum). Int J Agric Biol, 2008; 10: 85-88.

[128] Rodrigues C S, Laranjo M, Oliveira S. Effect of heat and $\mathrm{pH}$ stress in the growth of chickpea mesorhizobia. Current Microbiology, 2006; 
53: $1-7$.

[129] Peix A, Rivas-Boyero A, Mateos P, Rodriguez-Barrueco C, Martınez-Molina E, Velazquez E. Growth promotion of chickpea and barley by a phosphate solubilizing strain of Mesorhizobium mediterraneum under growth chamber conditions. Soil Biology and Biochemistry, 2001; 33: 103-110.

[130] Whitelaw M A. Growth promotion of plants inoculated with phosphate-solubilizing fungi. In Advances in Agronomy, 1999; 69: 99-151.

[131] Ole P, Pierdomenico P, Laurentius A C J. Voesenek, Flooding and low oxygen responses in plants. Functional Plant Biology, 2017; 44: 3-6.

[132] Yamauchi T, Colmer T D, Pedersen O, Nakazono M. Regulation of root traits for internal aeration and tolerance to soil waterlogging-flooding stress. Plant Physiology, 2018; 176: 1118-1130.

[133] Djanaguiraman M, Schapaugh W, Fritschi F, Nguyen H, Prasad P V. Reproductive success of soybean (Glycine max L. Merril) cultivars and exotic lines under high daytime temperature. Plant, Cell and Environment, 2018; 42: 321-336.

[134] Zaman M S U, Malik A I, Erskine W, Kaur W. Changes in gene expression during germination reveal pea genotypes with either quiescence or escape mechanisms of waterlogging tolerance. Plant Cell and Environment, 2018; 42: 245-258.

[135] Lui A, Xiao Z, Li M-W, Wong F L, Yung W S, Ku Y S, et al. Transcriptomic reprogramming in soybean seedlings under salt stress. Plant Cell and Environment, 2018; 42: 98-114.

[136] Sehgal A, Sita K, Bhandari K, Kumar S, Kumar J, Prasad P V V, Nuyyar $\mathrm{H}$. Influence of drought and heat stress, applied independently or in combination during seed development, on qualitative and quantitative aspects of seeds of lentil (Lens culinaris Medikus) genotypes, differing in drought sensitivity. Plant Cell and Environment, 2018; 42: 198-211.

[137] Gadhave K R, Devlin P F, Ebertz A, Ross A, Gange A C. Soil inoculation with Bacillus spp. modifies root endophytic bacterial diversity, evenness, and community composition in a context-specific manner. Microbial Ecology, 2018; 76: 741-750.

[138] Gadhave K R, Hourston J E, Gange A C. Developing soil microbial inoculants for pest management: can one have too much of a good thing? Journal of chemical ecology, 2016; 42: 348-356.

[139] Watts-Wlliams S J, Cavagnaro T R, Tyerman S D. Variable effects of arbuscular mycorrhizal fungal inoculation on physiological and molecular measures of root and stomatal conductance of diverse Medicago truncatula accessions. Plant Cell and Environment, 2018; 42: 285-294.

[140] Pivato B, Offre P, Marchelli S, Barbonaglia B, Mougel C, Lemanceau P, Berta G. Bacterial effects on arbuscular mycorrhizal fungi and mycorrhiza development as influenced by the bacteria, fungi, and host plant. Mycorrhiza, 2009; 19: 81-90.

[141] Barea J M, Jeffries P. Arbuscular mycorrhizas in sustainable soil-plant systems. In Mycorrhiza. Springer, 1995; pp.521-560.

[142] Bianciotto V, Andreotti S, Balestrini R, Bonfante P, Perotto S. Extracellular polysaccharides are involved in the attachment of Azospirillum brasilense and Rhizobium leguminosarum to arbuscular mycorrhizal structures. European Journal of Histochemistry, 2001; 45(1) 39-49.

[143] Artursson V, Finlay R D, Jansson J K. Interactions between arbuscular mycorrhizal fungi and bacteria and their potential for stimulating plant growth. Environmental Microbiology, 2006; 8: 1-10.

[144] Jeffries P, Gianinazzi S, Perotto S, Turnau K, Barea J-M. The contribution of arbuscular mycorrhizal fungi in sustainable maintenance of plant health and soil fertility. Biology and Fertility of Soils, 2003; 37: $1-16$.

[145] Linderman R G. Vesicular-arbuscular mycorrhizae and soil microbial interactions. Mycorrhizae in Sustainable Agriculture, 1992; (54): 45-70.

[146] Corkidi L, Allen E B, Merhaut D, Allen M F, Downer J, Bohn J, et al. Assessing the infectivity of commercial mycorrhizal inoculants in plant nursery conditions. Journal of Environmental Horticulture, 2004; 22: 149-154.

[147] Strigul N S, Kravchenko L V. Mathematical modeling of PGPR inoculation into the rhizosphere. Environmental Modelling \& Software, 2006; 21: 1158-1171.

[148] Gange A C, Gadhave K R. Plant growth-promoting rhizobacteria promote plant size inequality. Scientific Reports, 2018; 8: 13828.

[149] Habte M, Manjunath A. Soil solution phosphorus status and mycorrhizal dependency in Leucaena leucocephala. Appl Environ Microbiol, 1987; 53: 797-801.

[150] Dewey F, Wong Y L, Seery R, Hollins T, Gurr S. Bacteria associated with Stagonospora (Septoria) nodorum increase pathogenicity of the fungus. The New Phytologist, 1999; 144: 489-497.

[151] Mayak S, Tirosh T, Glick B R. Plant growth-promoting bacteria confer resistance in tomato plants to salt stress. Plant Physiology and Biochemistry, 2004; 42: 565-572.

[152] Belimov A, Hontzeas N, Safronova V, Demchinskaya S, Piluzza G, Bullitta S, et al. Cadmium-tolerant plant growth-promoting bacteria associated with the roots of Indian mustard (Brassica juncea L. Czern.) Soil Biology and Biochemistry, 2005; 37: 241-250.

[153] Marulanda A, Barea J, Azcón R. An indigenous drought-tolerant strain of Glomus intraradices associated with a native bacterium improves water transport and root development in Retama sphaerocarpa. Microbial Ecology, 2006; 52: 670. doi: 10.1007/s00248-006-9078-0.

[154] Nadeem S M, Zahir Z A, Naveed M, Arshad M. Preliminary investigations on inducing salt tolerance in maize through inoculation with rhizobacteria containing ACC deaminase activity. Canadian Journal of Microbiology, 2007; 53: 1141-1149.

[155] Figueiredo M V, Burity H A, Martínez C R, Chanway C P. Alleviation of drought stress in the common bean (Phaseolus vulgaris L.) by co-inoculation with Paenibacillus polymyxa and Rhizobium tropici. Applied Soil Ecology, 2008; 40: 182-188.

[156] Mhadhbi H, Jebara M, Limam F, Aouani, M E. Rhizobial strain involvement in plant growth, nodule protein composition and antioxidant enzyme activities of chickpea-rhizobia symbioses: modulation by salt stress. Plant Physiology and Biochemistry, 2004; 42: 717-722.

[157] Ahemad M, Khan M S. Toxicity assessment of herbicides quizalafop-p-ethyl and clodinafop towards Rhizobium pea symbiosis. Bulletin of Environmental Contamination and Toxicology, 2009; 82: 761-766.

[158] Ahemad M, Khan M S. Growth promotion and protection of lentil (Lens esculenta) against herbicide stress by Rhizobium species. Annals of Microbiology, 2010; 60: 735-745.

[159] Ahemad M, Khan M S. Effect of tebuconazole-tolerant and plant growth promoting Rhizobium isolate MRP1 on pea-Rhizobium symbiosis. Scientia Horticulturae, 2011; 129: 266-272.

[160] Upadhyay S, Singh J, Singh D. Exopolysaccharide-producing plant growth-promoting rhizobacteria under salinity condition. Pedosphere, 2011; 21: 214-222.

[161] Wani P A, Khan M S. Bioremediaiton of lead by a plant growth promoting Rhizobium species RL9. Bacteriology Journal, 2012; 2: 66-78.

[162] Wani P A, Khan M S. Nickel detoxification and plant growth promotion by multi metal resistant plant growth promoting Rhizobium species RL9. Bulletin of environmental contamination and toxicology, 2013; 91: 117-124.

[163] Islam M, Sattar M, Ashrafuzzaman M, Zulkerami B, Shamsuddoha A. Evaluating some Salinity Tolerant Rhizobacterial Strains to Lentil Production under Salinity Stress. International Journal of Agriculture \& Biology, 2013; 15: 499-504.

[164] Mesa-Marín J, Pérez-Romero J A, Mateos-Naranjo E, Bernabeu-Meana M, Pajuelo E, Rodríguez-Llorente, I D, et al. Effect of plant growth-promoting Rhizobacteria on Salicornia ramosissima seed germination under salinity, $\mathrm{CO}_{2}$ and temperature stress. Agronomy, 2019; 9: 655. 10.3390/agronomy9100655.

[165] Nadeem S M, Ahmad M, Zahir Z A, Javaid A, Ashraf M. The role of mycorrhizae and plant growth promoting rhizobacteria (PGPR) in improving crop productivity under stressful environments. Biotechnology Advances, 2014; 32: 429-448. 